\title{
The Bamiléke Economic Ground-Breaking Mission in the Bamenda Grasslands (Cameroon), 1961- 2010 ${ }^{1}$
}

\author{
Roland Mba Komo*, Nixon Kahjum Takor \\ The University of Bamenda, Cameroon
}

*Corresponding Author: Roland Mba Komo, The University of Bamenda, Cameroon

\begin{abstract}
The Bamiléke in the Cameroon Grasslands constitute one of the most dynamic social migrant groups distinguished for space occupation, business creation, expansion and a characteristic phenomenon of breaking new economic grounds. This paper seeks to examine the economic implantation of the Bamiléke in the Bamenda Grasslands. It argues that coming from a background of business inventiveness, the Bamiléke were shrewd entrepreneurs with flexible agencies who smartly identified, explored and exploited grey areas of economic opportunities in their host communities. In order to achieve this goal, the people to a large extent benefited from an accommodating environment, a tradition of solidarity network mediated through, but not reduced to a scheme of collective financial pooling which was mutually beneficial to all those who nursed interest in business activities. The article further contends that the Bamiléke economic miracle was a product of humble beginnings in petty trading, modesty in winning confidence, chanced situations, foresight for prospective gains and entrepreneurial spirit in taking and cushioning risk through multiple tactics of diversification. The paper made appeal to some selected primary and secondary sources and the conclusions were drawn after a qualitative historical analysis.
\end{abstract}

Keywords: Bamiléke, Bamenda Grasslands, Economic Opportunism, Entrepreneurial Spirit, GroundBreaking, Mission

\section{INTRODUCTION}

The issue of migration and adaptation of migrant communities into host destinations constitutes an essential interest in human history. This is given the dynamics in human environments and the unremitting quest of persons for improved socio-economic and political opportunities. It is evident that migration has played a pivotal role in (re-) configuring African societies in diverse ways. Aina and Baker $^{2}$ maintains that migration phenomenon in Africa like all human experiences throws up winners and losers and that these outcomes are determined by a combination of complex factors that are expressed in and through structures and agents. It is in this context that the paper examines the circumstances that conditioned the Bamiléke migration to the Bamenda Grasslands and appreciates the different ways by which they explored and exploited economic opportunities to become the key entrepreneurs in the area.

Among the myriads of groups that migrated and settled in the north-west Grasslands region of Cameroon especially in the $19^{\text {th }}$ and $20^{\text {th }}$ centuries, the Bamiléke stood out distinct in many respects. The people have been described as entrepreneurial and progressive people with high acumen for business. They are also seen as a very mobile ethnic group, only compared to the Hausa and the

\footnotetext{
${ }^{1}$ In 1961, the British Trust territory of Southern Cameroons reunified with the Republic of Cameroun and established a Federal state. The reunification of the two entities dissolved the international boundary that hitherto obstructed mobility of persons and goods. Being a very mobile and dynamic community, the Bamileke exploited the new corridor to systematically move to the Bamenda Grasslands in former British Southern Cameroons in their numbers for economic adventurism. In 2010, one of the most prominent and successful Bamiléke, business magnate Jonas Puwo who began in humble origins as a petty trader and developed to create multi million business investments in Bamenda with rippling effects across Cameroon and parts of Africa, died. This left a period of about half a century to appreciate the economic inroads the Bamiléke left in the Bamenda Grasslands of Cameroon.

${ }^{2}$ Tade Akin Aina \& Jonathan Baker (eds.), "Introduction" in The Migration Experience in Africa (Nordiska Afrikainstitutet, 1995), 11-12.
} 
Igbo. ${ }^{3}$ Eyongetah, Brain and Palmer consider them as progressive traders who adapted with alacrity and success to opportunities offered by the outside world."4

Other extant literatures ${ }^{5}$ on the economic activities of the Bamiléke have perceived them as "grabbers," always trying to get more economic opportunities at the expense of indigenous populations. As important as these findings maybe, this article does not in any way attempt to adopt a de-constructivist approach to earlier findings on Bamiléke economic outlook. Rather, it tries to reposition the Bamiléke within the context of access and competition over space exploitation in what Aina and Baker ${ }^{6}$ identifies as the game of 'winners and losers' characteristic of the zero-sum game. The article examines the process leading to the establishment of the Bamiléke in the Bamenda Grasslands, the strategy they used to mobilize capital and the economic activities/novelties they initiated that particularized their presence in the region as business heirs of the Igbo by the 1990s.

\section{BACKGROUND OF BAMILÉKE-BAMENDA RELATIONS}

The Bamiléke ${ }^{7}$ contacts with the Bamenda Grasslands could be traced back to the period antedating the establishment of the German Protectorate in 1884 when the area constituted one geographical entity. Movement from one part of the region, considered then as the Western Highlands, to the other was relatively fluid especially with the absence of rigid traditional frontiers. ${ }^{8}$ It was easy for traders to move along with their goods to proximate and distant market locations with relatively less impediments. Among the different 'diasporas' established in Cameroon by the Bamiléke, the Bamenda Grasslands was a major destination. The Bamenda Grasslands in spite of its geo-strategic importance as a major commercial entrepôt did not have an indigenous professional trading class whose identity is remembered anywhere, at least in literature and oral traditions out of the region. For the most part, trade was animated by the Hausa ${ }^{9}$ and Igbo traders who in terms of commercial mastery were by far more skillful than the traders from the Bamenda Grasslands. They acted in various capacities like landlords and brokers and due to their extensive mobility were versed with the market rhythms of demand, supply and profit speculation in the various commercial nodes. ${ }^{10}$ To these commercial precursors could be added the Bamiléke business group that remotely established commercial relations with the Bamenda and its environs.

The fluidity of relations between the people of the Bamenda Grasslands and the Bamiléke was more significant and reinforced during the German colonial period, especially with the construction of the road that linked the Bamiléke highlands and Bamenda plateau. The era of German rule in many respects was characteristic of intense 'Euro-Cameroonian' commercial activities among inland communities which presaged dynamic social interactions. It was in this move that many Bamiléke easily established contacts with communities in the Bamenda Grasslands that were closely connected to each other by trade activities. The ease with which the Bamiléke moved to and fro the Bamenda Grasslands was somehow affected by developments associated with the defeat of the Germans in Cameroon by a joint Anglo-French contingent and the eventual partition in 1916 of the territory into

\footnotetext{
${ }^{3}$ Tambi M. Eyongetah, Robert Brain and Robin Palmer, A History of Cameroon (London: Longman, 1987 ), 36.

${ }^{4}$ Ibid; R. Brain, "The Fontem-Bangwa: A Western Bamileke Group" in Claude Tardits, The Contribution of Enthnological Research to History of Cameroon Cultures, Vol. II (Paris: Editions du CNRS, 1973), 359.

5 Joseph L. Nfi, "Bamileke Immigrants, Commercial Farming and Land Disputes in Kumba Division, British Southern Cameroons" in American Journal of Social Sciences, Arts and Literature Vol. 3, No. 1, February 2016, 1-11; Meredith Terretta, Nation of Outlaws, State of Violence: Nationalism, Grassfields Tradition, and State Building in Cameroon (Athens, Ohio: Ohio University Press, 2014), 61-96.

${ }^{6}$ Ibid.

7 The expression 'Bamiléke' was first used by the German head of the Mbo Administrative Post in 1905. It was later adopted by the British and the French for administrative reasons to denote some closely-related communities at the south-eastern flank of the Bamenda plateau. The term Bamileke is a derivation of a poor pronunciation by the German explorer Gustav Cran of 'Mbameleku', a Mungaka (Bali)word translated loosely in English as "the people of the lowlands."

${ }^{8}$ V.G. Fanso, "Trans-Frontier Relations and Resistance to Cameroon-Nigeria Colonial Boundaries 1916-1945" (Doctorat D'Etat Thesis in History, University of Yaounde, 1982), 315.

${ }^{9}$ See N.F. Awasum, " The Hausa and Fulani in the Bamenda Grassfields 1903-1960" (Doctorat de 3e Cycle Thesis in History, University of Yaoundé, 1984).

${ }^{10}$ Nixon K. Takor, "The Bamenda Grasslands in Long Distance Trade c.1850-1961: Evolutionary Dynamics, Socio-Economic and Political Transmutations" (PhD Thesis in History, University of Yaoundé I, 2011), 107.
} 
two; four-firth to the French and a firth to the British. The partition placed the two regions astride an international border which somehow hindered the mobility of goods and persons either ways. ${ }^{11}$ The Milner-Simon decision of 1919 that confirmed the temporary partition of 1916 was indeed an impediment to the fluid mobility of the Bamileke and people of the Bamenda Grasslands as justified by Mukete:

The inconvenience suffered by the people was beyond description. Some members had to be subjected to the nuisance of performing border formalities whenever they wanted to meet their relatives across the border. Yes, the Milner/Simon line had come to stay and there was absolutely nothing the bewildered natives could do about it. ${ }^{12}$

This scenario of border policing went undiminished throughout the Anglo-French Mandate (19221945) and later Trusteeship (1946-1961) periods over the former German Cameroon. During these periods, shrewd tactics were employed by traders to circumvent the international borders. ${ }^{13}$ The end of Trusteeship and re-unification of the two territories, the Republic of Cameroun ${ }^{14}$ and British Southern Cameroons in $1961^{15}$ reignited the Bamiléke-Bamenda socio-economic relations as the borders were re-opened for the free movements of persons and goods.

In spite of the disruptions put to the movement of goods and persons between British and French Cameroons as earlier mentioned, the movement of the Bamiléke into the Bamenda Grasslands continued unperturbed. This was conditioned by a plethora of push and pull factors notably, geostrategic, economic, socio-cultural and political dynamics. From a geo-strategic perspective, the Bamiléke area and the Bamenda Grasslands all lay in the same geographical niche, the Western Highlands. There was no natural barrier to movement like forest, big rivers and mountains. This made it possible for the Bamiléke to have easy access into the Bamenda Grasslands in spite of the international demarcations that divided the people from 1916 to 1961.

From an economic consideration, trans-border trade was the most common way through which most Bamiléke entrepreneurs found themselves in the Bamenda Grasslands. Dongmo argues that trade remained a very crucial point for the Bamiléke migrations not only internally in Cameroon, but also to other parts of Africa like Gabon and Central African Republic. ${ }^{16}$ In 1925, an administrative report from Dschang stated that the Bamiléke traders who migrated to Victoria, Buea, Bamenda and Calabar were more and more numerous. ${ }^{17}$ Trade had a strong connecting influence as it integrated traders and border communities. Trade therefore became a major interface where people of different ethnic and cultural background created new social spaces straddling the artificially imposed frontiers. ${ }^{18}$ In this light, trade between the Bamiléke and the Bamenda Grasslands kept the prohibited borders permanently permeable. Besides these voluntary movements was the pressured migration engineered by some obnoxious French colonial administrative practices, notably, forced labor. French Cameroonians and Bamiléke were conscripted to work against their will in French projects like railways, roads and private plantations owned by the Europeans. Those who refused to submit to this coerced, non-remunerative labor recruitment locally called ndjock messi $i^{19}$ had no alternative but to

\footnotetext{
${ }^{11}$ Fanso, "Trans-Frontier Relations and Resistance," 165.

12 Victor E. Mukete, My Odyssey: The Story of Cameroon's Reunification (Yaoundé: Eagle Publishing, 2013), 29.

${ }^{13}$ See N.K.Takor, "Revisiting the motivations of informal institutionalized trade along the southwestern Cameroon-Nigeria border 1961-1994”. Social Science Research Dynamics, vol. 6, no.1. (June 2015), 86-109.

${ }^{14}$ On $1^{\text {st }}$ January 1960 , the end of trusteeship in the French governed sphere of Cameroon was sanctioned by the declaration of independence. At independence the territory took the name, The Republic of Cameroun.

${ }^{15}$ Unlike the French sphere of Cameroon that acceded unto independence as an entity on its own right, the British sphere gained independence by joining the independent Republic of Cameroun. This was done following a U.N organized plebiscite in February 1961.

16 J. L. Dongmo, Le dynamisme Bamileke (Cameroun) Volume II: la maitrise de l'espace urbain (Yaounde : Ceper, 1981), 53-54.

17 J.L. Nfi, "French Cameroonians in Politics of the Southern Cameroons 1922-1961" (DEA Thesis in History, University of Yaounde I, 2007), 64.

${ }^{18}$ Nixon K. Takor and Mathew B. Gwanfogbe, "The Political Implications of Trade in the Bamenda Grasslands 1889-1961” in Pan-Tikar Journal of History Vol. 1. No. 1 (March 2013), 23.

${ }^{19}$ Ndjock messi is a Bamileke word which means the same as forced unpaid labor. This was used during the colonial period when the Bamiléke were forced to work on French projects. This policy caused a lot of agitation
} 
flee. Forced labor was exacerbated by the exorbitant taxes imposed on the natives by the French colonial administration. This move triggered protest migrations to the Bamenda Grasslands (in the British sphere) which had a much more relaxed taxation policy engrained in the Indirect Rule system. ${ }^{20}$

On the social standpoint, the Bamiléke were influenced to migrate by the aura of opulence exhibited by those who had had contact experiences with the Bamenda Grasslands. It was customary for itinerant traders to display goods of ostentation like clothes, royal paraphernalia, flint guns, beads, iron implements, white kola (cola anomala) and salt that came from markets in the region. ${ }^{21}$ In like manner, stories of the hospitality of the people and openings to economic opportunities like available lands for farming became a source of admiration and attraction to those still in the Bamiléke homeland. These came on the heels of demographic increases,${ }^{22}$ that brought overbearing pressure on land resources and made it necessary for some of the people to look for means of survival elsewhere. The traditional system of land tenure in the Bamiléke land provided for succession of land titles to a single heir, usually the eldest son. As a result, the younger siblings who were landless had to migrate to seek for land and other vents of survival. ${ }^{23}$

Perhaps the most striking scenario in the migration of the Bamiléke to the Bamenda Grasslands was embedded in some political factors. Preponderant among them was inter-ethnic wars that orchestrated social instability and by extension deterred economic activities. These inter-village confrontations, which were mostly over land resources, included Baleveng and Bafou; Bangang and Balevang; and Balatchi and Babadjou. ${ }^{24}$ This disturbing local scenario was further exacerbated by some obnoxious French administrative policies notably the indigénat and associated police repression. This legal code relating to persons of "native status" or more technically "sujets" rather than "citoyens" permitted the French administrators both to try cases and impose summary disciplinary punishment. ${ }^{25}$ The policy of indigénat deprived French Cameroonians of their liberty of criticism, association and movement. Fanso intimates that by 1944, it was estimated that a plausible proportion of youths had escaped the district of Bafoussam as a result of indigénat and forced labour. ${ }^{26}$ In addition, French policies and practices such as appointment of "warrant chiefs," relocation of settlement and unpleasant forest regulations hurt the cultural pride of the people and an increasing proportion of the people desired to move out to "safer" areas.

The French administrative political repression was even more evident in May 1955 when the main nationalist party, the Union des Populations du Cameroun (UPC) was outlawed after staging an uprising to decry excessive French extortion and oppressive governance. This party which had as one of its lead mythic leaders, Ernest Oundie, a Bamiléke, had sizeable militants and sympathizers among the Bamiléke. This revolt led to the proscription of the party in French Cameroun, and crack down on its militants and sympathizers. A great number found sanctuary in the Bamenda Grasslands to seek

and protest migrations. See J. L. Dongmo, Le dynamisme Bamiléke (Cameroun) Volume II: la maitrise de l'espace urbain (Yaounde : CEPER, 1981), 202.

${ }^{20}$ Indirect Rule was a system of administration conceived by Federick Lord Lugard (Governor General of Nigeria and the Cameroons) around 1906. The successful implementation of the policy in Northern Nigeria motivated its extension to the British Cameroons (formally administered as an integral part of Nigeria) from 1922. By this colonial policy, the British administered her African territories through their traditional rulers and traditional institutions.

${ }^{21}$ Takor, "The Bamenda Grasslands in long distance trade c1850-1961", 84-104.

${ }^{22}$ The population of the area in 1933 was 320.000inhabitants. By 1954 it increased to 455.281. This population was spread over a surface area of $6700 \mathrm{~km}$ square giving a population density of about 149 persons per square km. See M. Kuete and A.F.Dikoume, “Espace, pourvoir et conflits dans les hautes terre de L'Ouest Cameroun: Espaces et société (Yaoundé :PUY, 2000), 2.

${ }^{23}$ Fidelis Limen (interview), farmer in Bamenda, Atuazire, 18 December 2009; See V. J. Ngoh, History of Cameroon since 1800 (Limbe: Presbyterian Printing Press, 2002), 19.

${ }^{24}$ Maurice Momo (interview), chief of Baleveng community and paramount chief of Menoua in Bamenda, chief of personnel Amour Mezam Bamenda, 5 November 2009.

25 Joseph A. Richard, Radical Nationalism in Cameroon: The Social Origin of the U.P.C. (Oxford: Clarendon Press, 1970), 27.

${ }^{26}$ Fanso, "Trans-Frontier Relations and Resistance," 362; RAB, file no. NW/Qa/f.1951/1, French Caneroonian Population in Bamenda Province 1951-52. 
political liberty and to continue with their political and economic activities. ${ }^{27}$ From the foregoing analysis, it is evident that for most parts of the pre and post-unification period, several Bamiléke continued to troop into the Bamenda Grasslands to carry on petty business activities like trading in household chores, tailoring, farming and arable crop commercialization.

Although the re-unification of the Cameroon brought an increasing number of the Bamiléke in the Bamenda Grasslands, their impact was not very imposing before the turn of the 1980s. This was because the economy of the region was tenaciously controlled by remnants of Igbo (Nigerian) business community which had established entrenched footholds as a result of the long years of administrative connections of the territory with Nigeria (1922-1961). The 1990s was a decade of extreme particularity for the Bamiléke. This was associated with the political upheavals in the country that was a response to an entrenched period of economic malaise which began in the mid-1980s.With the conduct of the Presidential Elections in Cameroon in October 1992, post-election violence plunged the Bamenda Grasslands, like most parts of the country into an atmosphere of insecurity and uncertainty. The government declared a State of Emergency which was followed by long periods of ghost towns with devastating consequences for the inhabitants of the region. ${ }^{28}$ This exercise saw arson on homes and property, looting of shops and attack on people. Some shops of foreigners especially the Igbo from Nigeria were also targeted and looted. ${ }^{29}$ As a measure to mitigate risk in their business activities, a significant section of the Igbo vacated the business scene in the Bamenda Grasslands. ${ }^{30}$ This created an economic vacuum, especially in the retail and wholesale trade network that the Bamiléke exploited profitably. It was against this background that a new wave of Bamiléke implanted themselves into the Bamenda Grasslands. They came in to break the economic monopoly which for long had been in the hands of the Nigerian Igbo entrepreneurs whose presence dates back to 1916 when the territory was informally integrated into the Nigerian administrative system by the British. The liberalization laws enacted in Cameroon in 1992 also gave the opportunity for the Bamiléke to carry out diverse investments in the Bamenda Grasslands.

\section{Dynamics of BAMILEKe Capital Mobilization}

After settling, the Bamiléke steadily began to develop interest on diverse economic activities. Among the numerous economic activities that they undertook, the most perceptible was trade. The Bamiléke passion for trade could best be understood from the local culture of commercial apprenticeship. This was done such that the young trader accompanied his father in trade expeditions. Moreover, he had to begin to know how to frugally use money. By the time the child attained maturity, he was sufficiently socialized in the structure of commercial practices. ${ }^{31}$ Most of the Bamiléke who established in the Bamenda Grasslands as traders began with some petty businesses, most often as itinerant traders. From this activity, they generated means to expand and also diversified to plough profits and mitigate risk. ${ }^{32}$ They started from very humble beginnings with different strategies of mobilising capital before expanding to become big entrepreneurs.

One of the most conspicuous means of capital mobilization was in the form of thrift and loan societies. These financial mutual aid schemes went by the name tontines. By this, (in)formal financial pooling were organized by members of the same community, village or interest groups to aid associates develop and expand their business plans. These associations were in fact organized by peer groups, close friends, relatives and members of the same trade or profession. ${ }^{33}$ The tontine as Alain

\footnotetext{
${ }^{27}$ Fanso, "Trans-Frontier Relations and Resistance," 207; RAB, file no. NW/TB/1940/1, Relations with French Authorities 1940-1961.

${ }^{28}$ SDF @ 25, The Struggle for Democracy and Good Governance (The Untold Story) (Limbe: Presbyterian Printing Press, 2015), 85-94.

29 (Interviews with) Ferdinand Onyeka, Igbo businessman, Kumbo, 27 August 2017; Johnson Emeka, businessman, Wum, 04 ${ }^{\text {th }}$ March, 2017; Hycienth Chuks Okafor (Chief), Former Vice President Nigerian Union in Bamenda, Bamenda, 05 November 2014.

${ }^{30}$ Ibid.

31 A. Dongmo, Le origin du sens commercial des Bamileke (Yaounde : Imprimerie St Paul, 1974), 46 ; also interview with Martin Nchinda, aged 75, business retiree, Sisia III Bamenda, 20 July 2017.

${ }^{32}$ Jules Akenfack (interview), businessman, Nkambe, 22 April 2017.

${ }^{33}$ V.G. Fanso, Cameroon History for Secondary Schools and Colleges...vol.1, 65.
} 
Henry observed, was a strictly structured social agency with strict protocols of admitting members ${ }^{34}$ and financial contribution, solemn ritual of financial distribution and unforgiving sanctions on those who deviated procedures. There was no clemency for defaulters. Even death was no pardon for the fulfillment of financial commitment as debts were obligatorily taken care of by sureties. These strict policies, however, did not conceal the spirit of solidarity that spun the people together. The members were compelled to exude love and care to one another in moments of joy as well as misfortune. ${ }^{35}$ These tontines involved modest as well as very huge sums of money, sometimes up to milliards. ${ }^{36}$ Commenting on the strength of tontines, Jua contends that:

The negative effects ... on the intermediation capabilities of local banks were exacerbated by the spread of "tontines" or "njangis"... A BEAC executive estimated in 1984 that about $80 \%$ of all Cameroonians belonged to one or more "njangis"- essentially social or clan affinity groups, that played the role of informal credit cooperatives.... Banking sources estimated that credits circulating in these groups in 1984 ranged from 200 billion to 1.5 trillion FCFA. During this same period, the formal banking sector provided only 800 billion FCFA in loans. ${ }^{37}$

Given this strategy, the primary purpose of tontine was the concentration of protection of wealth and the prevention of its dissipation through the demands of kin. In the face of inevitable mistrust, financial scarcity, tontines helped to build trust, and to establish kindness and mutual aid that became the driving force for business investments among the Bamiléke.

Aligning, the Bamiléke strategy of mobilizing capital exclusively to tontines would be synonymous to reducing their vitality in wealth creation to a single stratagem. The mutual aid scheme that was centred on solidarity had another facet in building Bamiléke business aptitude. In this case, those who had made some funds readily gave start-up capitals to their kins. Eric Azapze, a well-established Bamiléke petty trader and owner of a residence in Bamenda town started with a capital of 10.000FCFA given to him by his older brother. Fidel Limen had a similar experience where the elder sister assisted him with the sum of 100.000FCFA to begin a trade in jewelleries. From this business he made sufficient profits and turned over to the buying and selling of second handed school books which had become very profitable as a result of a dramatic leap in the school population in Bamenda town. ${ }^{38}$ Besides, the solidarity aid schemes, the people were able to build business capital by individual inventiveness of borrowing and commercial prospection. Rowlands demonstrates this by using the example of:

... a boy who would borrow the money to buy a box of soap from a wholesaler in the market, would sell each bar individually on the streets or in the market of outlying villages and would gradually accumulate sufficient capital from street hawking.... ${ }^{39}$

Illustrative of this commercial strategy was the case of David Tchoffou who began business in Bamenda in the 1950s by buying and at times borrowing soap, matches, kerosene, lamp chimney and wicks in Bamenda town and then retailing them in localities like Guzang, Widekum, Bali, Bambili and Bafut. After making a fortune out of the itinerant business in these commodities for close to a decade, he expanded to the sale of second hand dresses commonly called okrika in enclaved localities of the region around Nso and Nkambe where the demand was high. ${ }^{40}$ This was the same strategy of economic ascendance that other prominent Bamiléke entrepreneurs like Jean Ngoula, Jean Tatsa,

\footnotetext{
${ }^{34}$ To become part of a tontine, even for relatively small contributions, the candidate had to be presented by one of the members who acted as his sponsor. An investigation of the candidate's morals was carried out. Once the candidate was voted in, the day he benefitted the fund, another member had to act as guarantor for his repayments. See H.Alain, Alain, "Using Tontines to run the economy" (Les Amis de l'Ecoles de Paris, French Development Agency, June 2003) in www.ecole.org/en/535/VC190603-ENG.pdf. Accessed 7/01/2019.

35 Alain, "Using Tontines to run the economy."

${ }^{36}$ Ibid

${ }^{37}$ Nantang Jua, "State, Oil and Accumulation," in P. Geschiere and P. Konings, Pathways to Accumulation in Cameroon (Leiden: Editions Karthala et Afrika-Studiecentrum, 1993), 154-155.

38 Eric Azape(Interview), trader, Bamenda, 05 November, 2015; Fidel Limen (Interview), Bamenda, 05 November, 2014.

${ }^{39}$ M. Rowlands, "Accumulation and the Culture of Politics of Identity in the Grassfields." In P. Geschiere and P. Konings, Pathways to Accumulation in Cameroon (Leiden: Editions Karthla et Afrika-Studiecentrum, 1993$), 74$.

${ }^{40}$ David Tchoffou, businessman Bamenda, 17 July 2016.
} 
Jonas Puwo took in their economic ground-breaking mission in the Bamenda Grasslands. According to $\mathrm{Nji}$, the success of the Bamiléke stemmed from their dynamism, combative spirit, risk taking and a close network of solidarity. ${ }^{41}$ Fanso supports the economic vitality and success of the Bamiléke when he states:

The Bamiléke were, and still are, amongst the most energetic and resourceful peoples of Western-Equatorial Africa, compared only with the enterprising Igbo of Nigeria, and reputed for being ruthless in acquiring wealth and other advantages for themselves. They were generally more successful in securing employment and other undertakings than other peoples in Cameroon. ${ }^{42}$

Besides, some of the Bamiléke especially those who were still emerging gave no indulgence to rest as they made use of all the days of the week. They were noted for taking full days of commercial activities on Sundays which was traditionally a bank holiday for business activities. ${ }^{43}$ Following this form of tacit commercial accumulation, it was easier for the Bamiléke to initiate and establish new economic ventures. In the major towns of the Bamenda Grasslands therefore, the Bamiléke were involved in different economic activities.

\section{CONSTRUCTION AND DiversifiCATION OF ECONOMIC OPPORTUNITIES}

As the Bamiléke settled in the Bamenda Grasslands in their numbers ${ }^{44}$, they systematically integrated themselves into local communities. The process of integration was facilitated by their knowledge of the terrain having begun as itinerant traders in most parts of the region before the opening of the international borders with reunification. They went through their first acquaintances not only aware of commercial opportunities but of other potential avenues of business expansion. Unlike the Hausa and the Igbo who were mostly dependent on petty and wholesale trade ventures, the Bamiléke developed multipurpose economic agendas, some novel to the business environment of the Bamenda Grasslands. It is not easy to exhaustively capture the range of economic activities that the Bamiléke initiated in the region. This is given that they were numerous and spanned across the primary, transformative and tertiary tiers of the economy. In spite of the diversity in activities, all centred on an alert mission of wealth accumulation. An inventory into some of these economic missions would bear proof to this vision.

Although perceived as traders, the Bamiléke prior to their establishment in the Bamenda Grasslands had good knowledge of the availability of abundant farming lands. They were equally aware of the culture of crop production that was principally in subsistence considerations. Equipped with these facts, they nursed a desire to invest in agricultural activities that extended the existing practices. At first, they rented land upon which they carried out arable crop cultivation. After gaining acquaintances with the land owners, within a few (about two-three) years of farming, they went on to purchasing parcels of land which they continued to cultivate but with prospections to develop into real estates. Gradually, they came to occupy parcels of land in the major towns of the Bamenda Grasslands like Bamenda, Ndop, Kumbo, Wum and Nkambe. In some cases, land was acquired by simply offering the land owners and the traditional ruler or fon some (ostentatious) gifts like roofing sheets and apparels. ${ }^{45}$ This was similar to the system of land ownership in the Bakweri areas as articulated by ClarenceSmith that: "The "traditional" way for a "stranger farmer" to get land was to kill a pig for the villagers. He then received the usufruct of the land without any further payment of rent. ${ }^{46}$ Since the Bamiléke accumulated wealth from various businesses, they adjusted to the increasing value of land by buying parcels of land for immediate and prospective use with financial fortune. Dongmo identifies some of the peculiarities common to the Bamiléke on land matters. These included

\footnotetext{
${ }^{41}$ Ajaga Nji (interview), Professor of Rural Sociology, Dschang, 12 January 2009.

${ }^{42}$ V.G. Fanso, Cameroon History for Secondary Schools and Colleges Vol. 2, The Colonial and Post-Colonial periods (Hong Kong: Macmillan Education Ltd, 1989), 168.

${ }_{43}$ Marcel Bofang (interview), Bamileke Petty Trader, Bamenda, 15 July, 2016.

44 By 1976, there were about 4936 Bamileke as Dongmo observes. See Dongmo, Le Dynamisme Bamileke, vol.1, 211.

${ }^{45}$ Moses Ntchaika (interview), farmer, Ndop, 14 June 2016.

${ }^{46}$ William Gervase Clarence-Smith, "Plantation versus Smallholder Production of Cocoa: The Legacy of the German Period in Cameroon," in P. Geschiere and P. Konings (eds.) Pathways to Accumulation in Cameroon (Leiden: Editions Karthala et Afrika-Studiecentrum, 1993), 205.
} 
acquisition of inhabitable land, ${ }^{47}$ buying land without titles and depending on rented land ${ }^{48}$ The Bamiléke generally had high speculation for land. That was why they occupied in the 1960s and 1970s parts of lands shadowed by the cliffs of the Bamenda Station and other squelchy areas especially in the Ndop Plain which the indigenes did not find to have credible economic value. Most of the lands acquired were primarily used for farming before other projects could be envisaged. Apart from these, those who had greater financial power by the 1980s like Jean Tatsa, Jonas Puwo and Jean Ngoula moved and secured extensive lands at the centre of the town, well in anticipation of the urban revolution of the settlement in the 1990s. ${ }^{49}$

The Bamiléke cultivated many kinds of food crops, and vegetables but their focus was mainly on commercial crops like coffee, cassava and rice that were established in areas that had corresponding edaphic support. The scale of these farming cultures was larger than the pre-existing ones given that it was supported by the same spirit of family and group solidarity that accompanied their business culture. Commercial agriculture was an important source of initial capital for some of the early settlers. In the Ndop plain for instance, most of those who began cultivating rice were Bamiléke. A classic example was Andreas Mbonyi who came in the 1960s and began a production scheme of about 1.5 tonnes of rice. This production fetched him some 1.200.000FCFA per annum in the $1980 \mathrm{~s} .{ }^{50}$ With this fortune, he rapidly developed to become one of the most successful grocery store keepers in Ndop. While the people invested in market-oriented agriculture, they reduced subsistence drain by producing for their households a wide variety of arable crops like bean, cocoyam, okra, potato and fruits for domestic consumption. ${ }^{51}$

Away from crop farming, the people were also involved in livestock breeding. They kept birds and animals, partly for home consumption but more importantly, for exchange. They were renowned for rearing fowls, goats and pigs. These were practices they transported from their host communities into the Bamenda Grasslands. Among the livestock bred, table-bird and pig were the most outstanding. According to Nchinda, quite a substantial number of Bamiléke who migrated to Bamenda were involved in the rearing of fowls for sale and pigs for barbecues. By the turn of the 1980s, the value of pigs had increased immeasurably due to the demand it commanded for barbecues and traditional/public festive occasions. ${ }^{52}$ As the demand for pork increased, the culture intensified and became a main business especially for the Bamiléke of Bamboutous origin of the Bamileke Highlands from the late 1990s to the first decade of 2000.

Complementing investments on agriculture the Bamiléke were also very active in some transformative (secondary) sector activities. In this direction, they manufactured bread and other pastries in local ground-mounted ovens and progressively developed into modern bakeries. By the turn of the millennium in 2000, over 80 percent of bakeries in Bamenda town were owned by the Bamiléke. These included Prince Bakery at Sonac Street, Jean Jeannot Bakery at Savannah Street and A\&G Bakery at Meta Quarters, in Bamenda. These bakeries operated at the same time as general grocery shops for domestic goods like beverages, alcoholic and non-alcoholic drinks, confectioneries and household utensils. Among the secondary productive activities, the most outstanding in terms of capital investment was the detergent production factory created in the 1996 at Mile 4 Nkewn, Bamenda by Jonas Puwo which produced two soap brands, International Soap and Super Soap. This industry geared in full capacity supplying not only Bamenda but targeted the rest of the country and the African continent. The soap industry was a major revolution in Bamiléke ground breaking mission in Bamenda as it had an employment capacity of about 100 people. ${ }^{53}$

\footnotetext{
${ }^{47}$ These lands in effect were inedificandi (protected conserved areas) as laid down in Ordinance no.74-1 of 6 July 1974 to Establish Rules Governing Land Tenure in the United Republic of Cameroon. See Article 15(2), lands free from any effective occupation.

48 J. L. Dongmo, Le dynamisme Bamileke (Cameroun) Volume II: la maitrise de l'espace urbain (Yaounde: CEPER, 1981), 82-116.

${ }^{49}$ Tanyi Tchoffo Thomas (interview), welder, Bamenda, 18 October, 2009.

${ }^{50}$ Amblesil Njekwei (interview), Secondary school teacher and daughter of a Bamileke, Bamenda, 08 February, 2019.

${ }^{51}$ Vera N. Tenjoncha, "The Bamileke Community in Ndop Plain Bases of Implantation and Impact 1955-1993" (DIPES II Thesis in History, The University of Bamenda, 2014), 74.

${ }_{52}$ Martin Nchinda (Interview).

${ }^{53}$ Roger Nkamgna, Retired Petroleum Engineer and UPC militant since the 1950s, Bamenda, 03 February, 2010.
} 
In the tertiary sector, the people introduced a striking break with the status quo in the domain of hardware shops, public transportation, gas station and hotel services. In the 1990s, some major Bamiléke multi-million national wholesale/retail distribution business plants were extended to some localities in the Bamenda Grasslands with concentration in Bamenda town. These included COGENI, SOREPCO, FOKOU and QUIFEROU. The business plants were characteristic of superstores dealing with a wide range of products in home appliances, furniture, school and office stationery, food, maintenance, construction materials, tiles and sanitary equipment, electrical equipment. These stores operated strategically by aligning business operations to the forces of demand and supply. For instance from August to October, attention was mostly skewed towards furnishing school and office stationeries to meet the demands for school resumption while in November and December, the stock of conspicuous consumption like wine, gifts of various kinds, electronic appliances, toys, rice and vegetable oil became outstanding. Meanwhile, one stable category of goods that did not vacillate with the dynamic demand sequence was hardware materials notably construction materials. This was given the fact that constructions went on year round with people competing to appropriate the latest materials and technologies for their homes. Considering the high demand for building materials, many Bamiléke diversified their investments in small scale stores retailing some of the construction wares like cement, roofing, electrical and plumbing materials. ${ }^{54}$

As usual, the development of the transport business was a product of careful foresight, envisioned plan of diversification that always took a grass-to-grace approach. Diversification was one of the common features of the Bamiléke to minimize business risk (and expand on profits) as Rowlands observes. ${ }^{55}$ Jean Tatsa who migrated to Bamenda in the early 1950s began by trading in fabrics which he bought in Nigeria and Victoria and retailed them at different localities in the Bamenda Grasslands. By 1960, he had amassed significant wealth from the cloth business. This gave him the advantage to expand to freight transportation. He began with one truck in 1956 and steadily increased the number to twenty. By 2010, he had over thirty trucks. ${ }^{56}$

Another Bamiléke, Etienne Lombagho recounts that he came to Bamenda in 1959 and began as a petty trader. He then changed to the sale of textile up to 1972. From there, he served as a driving aide ("motor boy") for a wagon bought by his older brother till 1976 when he became driver for a 19 seater DYNA bus bought by his brother. As driver, he transported passengers and goods to places like Wum, Douala, Mamfe, Nkambe and Bafoussam. In 1979, he made sufficient money and bought his first transport vehicle. By 1981, he already had eight cars in the transport sector in Bamenda plying different itineraries from Bamenda to other parts of the country. The first inter-urban travel agency in Bamenda was opened by Jean Kuete known as Le Bien Voyages in the late 1980s. Le Bien introduced the first Classic transport double-deck inter-urban carrier in the town of Bamenda. This bus and others transported passengers to and from the towns of Yaoundé and Douala. ${ }^{57}$

The vision of Jean Kuete was emulated shortly after by other enterprising Bamiléke businessmen. In the early 1990s, Jonas Puwo founded the Garanti Express Bus Service. Puwo routinely began as a petty trader and later opened a bar and musical Opera Spot (Ghana Bar) in Nkwen, Bamenda which made hits around the mid-1960s and 1970s. He also amassed important wealth as a large scale retailer of fabrics and as local currency exchange dealer at the time when the legal tender in the Bamenda Grasslands (coterminous to part of former British Southern Cameroons) had been changed in 1962 under the Federal project in Cameroon from the Pound Sterling to Franc CFA. Amour Mezam Bus Agency came on the heels of Garanti Express and was initiated by Jean Ngoula. He entered the transportation sector informally in 1965 after commencing as a petty retailer of fabric and tailor, where he made considerable profits. By the late 1960s and 1970s, he bought DYNA-made buses and began plying different intra-regional and inter-urban locations. In the early 1990s, he advanced

\footnotetext{
${ }^{54}$ Elias Fonkwe Tamun (interview), retired teacher of Basel Mission and businessman, Bamenda, 18 July 2016.

${ }^{55}$ M. Rowlands, "Accumulation and the Culture of Politics of identity in the Grassfields," in P. Geschiere and P. Konings, Pathways to Accumulation in Cameroon (Leiden: Editions Karthla et Afrika-Studiecentrum, 1993$), 74$. ${ }^{56}$ Elias Fonkwe Tamun (interview).

${ }^{57}$ Etienne Lombagho (HRH), Traditional head of Babadjou Community in Bamenda, Retiree Businessman and a Farmer, Cow Street Bamenda, 27 July 2016.
} 
further, acquired new carriers and opened an Inter-urban travel agency (Amour Mezam and Co. Ltd) in Bamenda with branches in localities like Ndop, Kumbo, Nkambe, Fundong and Wum. ${ }^{58}$

The emergence of these inter-urban and intra-regional transport services brought a new form of organization in public transportation. It came to reduce the pressure and disorganization that used to be characteristic of the public motor parks in different localities of the Bamenda Grasslands. Besides the transportation of persons, the new transportation system brought in new courier services that were more reliable and expedient in freighting and money transfers. Alongside these transport services, some of the proprietors developed hotel facilities with the principal objective of providing lodging, restauration and recreational facilities to commuters as well as to the local population that was gradually accustoming to urban lifestyle. Indicative of this move were Le Bien Hotel and International Hotel founded by Jean Kuete and Jonas Puwo, respectively. ${ }^{59}$

Considering that the transportation sector was growing in importance with increases in the number of fleets and also gauging the growing number of public and private automobiles in the region, some Bamiléke entrepreneurs expanded their business to the petrol sector. This process was readily facilitated by the vacuum left by the dealers, in fuel (mainly Igbos) that came from Nigeria. The Igbo businessmen had abandoned the activity as result of the lengthy shutdowns and destructions that characterized the period of political instability in Cameroon in the opening years of the 1990s. During this socio-political crisis, it was difficult for fuel from Nigeria commonly called zoa-zoa to be brought to the Bamenda Grasslands. This fuel was widely used in the region and filtered in formally and informally from different windows opening up in Nigeria, notably in the Nkambe plateau, part of Northern Nigeria and the Widikum-Mamfe Basin linked to South-Eastern Nigeria. In the absence of any other major alternative, zoa-zoa was widely marketed and consumed in the Bamenda Grasslands. The absence of this product in the Bamenda Grasslands as a result of the political troubles of the 1990s provided opportunity for some Bamiléke businessmen like Jean Tatsa to diversify into formal oil filling stations. They did this by buying distribution rights from multinational companies such as MOBILE and TEXACO. ${ }^{60}$

\section{CONCLUSION}

The implantation of the Bamiléke in the Bamenda Grasslands as projected was a process that started long before the independence and reunification of the Cameroons in 1960/61. The motivations of migration oscillated on some pull factors in the Bamenda Grasslands that shared proximate cultural and most especially geo-strategic links with the Bamiléke Highlands of West Cameroun. On the other hand, some repelling factors in the Bamiléke homeland, notably population pressure and political oppression of French colonial administration contributed in the steady migration of the people out of Bamiléke land. One of such areas was the Bamenda Grasslands that distinguished itself as an economic entrepôt wiring several proximate and distant communities with the markets of Northern and South-Eastern Nigeria. Besides, the region had vast acreages of unexploited lands which could readily accommodate new ventures. Commencing like itinerant petty traders, the Bamiléke like their economic predecessors, the Hausa and Igbo gradually gained mastery of the environment as a result of their humble commercial contact experiences.

The opportunity of the Bamiléke to make quick economic inroads to the Bamenda Grasslands was mitigated by two key factors; the partition of Cameroon into British and French spheres, with the Bamiléke chiefdoms falling in the French section and, the presence of the enterprising Igbo commercial group that entered the territory especially in the period 1916-1961 (when the region was governed as an integral part of Nigeria), and took control of the business sphere in the entire British Southern Cameroons. The restrictions of the international boundary between the two Mandate and later Trust territories inhibited, though did not forestall cross border mobility. The dissolution of the borders in 1961 following the reunification of the territory gave the Bamiléke the leeway to successively migrate into the Bamenda Grasslands. Although, coming from different social entities and migrating for dissimilar reasons, the Bamiléke communities that entered the Bamenda Grasslands developed a common posture which was centred on, but not totally reduced to, economic adventurism

\footnotetext{
${ }^{58}$ Maurice Momo (interview). Also see Marcel Bobga Sama, "Public Bus Transportation Agencies in Bamenda. 1962-2008: Evolution and Impacts" (MA Dissertation in History, The university of Bamenda, 2018).

${ }^{59}$ Idem.

${ }^{60}$ Mesack Fon Ajagah (interview), retiree trader, Metta Quarter Bamenda, 16 July 2009.
} 
and business inventiveness. This vision developed gradually and blossomed from the 1990s when, economic lockdowns associated with political crisis in Cameroon compelled many Igbo to surrender business activities in the Bamenda Grasslands and other parts of Cameroon. Exploiting this vacuum, the Bamiléke marshalled their long-nursed economic project into action. This project rested on some complex factors emanating from a frugal outlook, close-knit solidarity strategy partly expressed in a financial mutual aid scheme variously known as tontines. With this socially construed financial empowerment coupled with individual strategies of wealth accumulation, the people took advantage of the 'friendly' economic environment to acquire land, initiate commercial agriculture and develop businesses at the primary, secondary and tertiary sectors. They particularly made astonishing business strides in commercial agriculture, retail and wholesale groceries, development of modern public transportation system, large scale freighting, fuel filling stations, bakeries and the soap factory production. This economic miracle was a product of humble beginnings in petty trading, modesty in winning confidence, foresight for prospective gains and entrepreneurial spirit in taking and cushioning risk through multiple tactics of diversification.

\section{REFERENCES}

[1] Aina, Akin Tade \& Baker, Jonathan (eds.). "Introduction" in The Migration Experience in Africa. Nordiska Afrikainstitutet, 1995.

[2] Alain, H. "Alain, Using Tontines to run the economy," Les Amis de l'Ecoles de Paris, French Development Agency, June 2003 in www.ecole.org/en/535/VC190603-ENG.pdf. Accessed 7/01/2019.

[3] Awasum, N.F. "The Hausa and Fulani in the Bamenda Grassfields 1903-1960." Doctorat de 3e Cycle Thesis in History, University of Yaoundé, 1984.

[4] Brain, R. "The Fontem-Bangwa: A Western Bamileke Group." In Claude Tardits. The Contribution of Enthnological Research to History of Cameroon Cultures, Vol. II. Paris: Editions du CNRS, 1973.

[5] Clarence-Smith, William Gervase. "Plantation versus Smallholder Production of Cocoa: The Legacy of the German Period in Cameroon." In P. Geschiere and P. Konings (eds.) Pathways to Accumulation in Cameroon. Leiden: Editions Karthala et Afrika-Studiecentrum, 1993.

[6] Dongmo, A. Le origin du sens commercial des Bamiléke. Yaounde : Imprimerie St Paul, 1974.

[7] Dongmo, J. L. Le dynamisme Bamiléke (Cameroun) Volume II: la maitrise de l'espace urbain. Yaounde : Ceper, 1981.

[8] Le dynamisme Bamiléke (Cameroun) Volume II: la maitrise de l'espace urbain. Yaounde : Ceper, 1981.

[9] Eyongetah, M. Tambi, Brain, Robert and Palmer, Robin. A History of Cameroon. London: Longman, 1987, 36.

[10] Fanso, V.G. "Trans-Frontier Relations and Resistance to Cameroon-Nigeria Colonial Boundaries 19161945." Doctorat D'Etat Thesis in History, University of Yaounde, 1982.

[11] _Cameroon History for Secondary Schools and Colleges Vol. 1: From Pre-historic Times to the Nineteenth Century. London: Macmillan, 1989.

[12] _ Cameroon History for Secondary Schools and Colleges Vol. 2, The Colonial and Post-Colonial periods. Hong Kong: Macmillan Education Ltd, 1989.

[13] Jua, Nantang. "State, Oil and Accumulation." In Geschiere P. and Konings, P. Pathways to Accumulation in Cameroon. Leiden: Editions Karthala et Afrika-Studiecentrum, 1993.

[14] Kuete, M. and Dikoume, A.F. "Espace, pourvoir et conflits dans les hautes terre de L'Ouest Cameroun: Espaces et société. Yaoundé: PUY, 2000.

[15] Mukete, Victor E. My Odyssey: The Story of Cameroon's Reunification. Yaounde: Eagle Publishing, 2013.

[16] Nfi, L. Joseph. "Bamileke Immigrants, Commercial Farming and Land Disputes in Kumba Division, British Southern Cameroons.” In American Journal of Social Sciences, Arts and Literature Vol. 3, No. 1, February 2016.

[17] "French Cameroonians in Politics of the Southern Cameroons 1922-1961." DEA Thesis in History, University of Yaounde I, 2007.

[18] Ngoh, V. J. History of Cameroon since 1800. Limbe: Presbyterian Printing Press, 2002.

[19] Rowlands, M. “Accumulation and the Culture of Politics of Identity in the Grassfields." In Geschiere P. and Konings, P. Pathways to Accumulation in Cameroon. Leiden: Editions Karthla et AfrikaStudiecentrum, 1993.

[20] Sama, Bobga Marcel. "Public Bus Transportation Agencies in Bamenda. 1962-2008: Evolution and Impacts." MA Dissertation in History, The University of Bamenda, 2018. 
[21] Tenjoncha, N. Vera. "The Bamileke Community in the Ndop Plain: Bases of Implantation and Impact 1955-1993.” DIPES II Thesis in History, The University of Bamenda, 2014.

[22] Takor, K. Nixon. "The Bamenda Grasslands in Long Distance Trade c.1850-1961: Evolutionary Dynamics, Socio-Economic and Political Transmutations." PhD Thesis in History, University of Yaounde I, 2011.

[23] _Revisiting the motivations of informal institutionalized trade along the southwestern Cameroon-Nigeria border 1961-1994.” Social Science Research Dynamics, vol. 6, no.1, June 2015.

[24] Takor, K. Nixon and Gwanfogbe, Mathew B. "The Political Implications of Trade in the Bamenda Grasslands 1889-1961.” In Pan-Tikar Journal of History Vol. 1. No. 1, March 2013.

[25] Richard, A. Joseph. Radical Nationalism in Cameroon: The Social Origin of the U.P.C. Oxford: Clarendon Press, 1970.

[26] Terretta, Meredith. Nation of Outlaws, State of Violence: Nationalism, Grassfields Tradition, and State Building in Cameroon. Athens, Ohio: Ohio University Press, 2014.

[27] SDF @ 25, The Struggle for Democracy and Good Governance (The Untold Story). Limbe: Presbyterian Printing Press, 2015.

[28] United Republic of Cameroon, "Ordinance no.74-1 of 6 July 1974 to Establish Rules Governing Land Tenure in the United Republic of Cameroon."

\section{ARCHIVAL SOURCES}

\section{Regional Archives Bamenda (RAB)}

[1] File no. NW/TB/1940/1, Relations with French Authorities 1940-1961.

[2] File no. NW/Qa/f.1951/1, French Cameroonian Population in Bamenda Province 1951-52.

\section{Interviews}

[3] Akenfack, Jules. Businessman, Nkambe, interviewed 22 April 2017.

[4] Azape, Eric. Trader, Bamenda, interviewed 05 November, 2015

[5] Bofang, Marcel. Bamileke Petty Trader, Bamenda, interviewed 15 July, 2016.

[6] Emeka, Johnson. Businessman, Wum, interviewed 04 March, 2017.

[7] Fonkwe, Elias Tamun. Retired teacher of Basel Mission and businessman, Bamenda, interviewed 18 July 2016.

[8] Limen, Fidelis. Farmer in Bamenda, Atuazire, interviewed 18 December 2009.

[9] Limen, Fidel. Trader. Bamenda, interviewed 05 November, 2014.

[10] Lombagho, Etienne (HRH). Chief of Babadjou Community in Bamenda and retired businessman and a farmer, Cow Street Bamenda, interviewed 27 July 2016.

[11] Momo, Maurice. Chief of Baleveng community and paramount chief of Menoua in Bamenda, chief of personnel Amour Mezam Bamenda, interviewed 5 November 2009.

[12] Nchinda, Martin. Business retiree, Bamenda, interviewed 20 July 2017.

[13] Njekwei, Amblesil. Secondary school teacher and daughter of a Bamileke, Bamenda, interviewed 08 February, 2019.

[14] Nji, Ajaga. Professor of Rural Sociology, University of Dschang, interviewed 12 January 2009.

[15] Nkamgna, Roger. Retired Petroleum Engineer and UPC militant since the 1950s, Bamenda, interviewed 03 February, 2010.

[16] Ntchaika, Moses. Farmer, Ndop, interviewed 14 June 2016.

[17] Okafor, Chuks Hycienth (Chief). Former Vice President Nigerian Union in Bamenda, interviewed 05 November 2014.

[18] Onyeka, Ferdinand. Igbo businessman, Kumbo, interviewed 27 August 2017.

[19] Tanyi Tchoffo Thomas. Welder, Bamenda, interviewed 18 October, 2009.

[20] Tchoffou, David. Businessman Bamenda, interviewed 17 July 2016.

\section{AUTHORS' BIOGRAPHY}

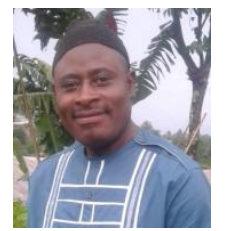

Roland Mba Komo is a Doctorandus in the Department of History and Archaeology at the Faculty of Arts, The University of Bamenda (Cameroon). He is a professional teacher of History for Secondary and High Schools in Cameroon with over seventeen years of proven experience. He is a member of the Cameroon History Society and a superintendent of Ordinary Level History at the Cameroon General Certificate of Examination (GCE) Board. His research interest is currently focused on facets of economic and social history. 
Dr. Nixon Kahjum Takor is currently an Associate Professor of History and Chair of the Department of History and Archaeology at the Faculty of Arts, The University of Bamenda in Cameroon. He is a member of the Business History Congress and the Cameroon History Society. His teaching and research interests over the years has centered on aspects of economic and social history, public history, didactics of history, historiography and historical research methods.

Citation: Roland Mba Komo, Nixon Kahjum Takor. "The Bamiléke Economic Ground-Breaking Mission in the Bamenda Grasslands (Cameroon), 1961- 2010” International Journal of Humanities Social Sciences and Education (IJHSSE), vol 6, no. 3, 2019, pp. 6-18. doi: http://dx.doi.org/10.204 31/2349-0381.0603002.

Copyright: (C) 2019 Authors. This is an open-access article distributed under the terms of the Creative Commons Attribution License, which permits unrestricted use, distribution, and reproduction in any medium, provided the original author and source are credited. 